УДК 550.34

DOI: $10.23671 /$ NNC.2014.2.55435

\title{
NORMALIZED ACCELERATION RESPONSE SPECTRA FOR TBILISI CITY WITH SEISMOLOGICAL PARAMETERS AND SITE EFFECTS
}

\author{
() 2014 P. Rekvava ${ }^{1}$, Prof. Dr., K. Mdivani², Dr. \\ Georgian National Association for Earthquake Engineering and Engineering \\ Seismology, Tbilisi, Georgia, ${ }^{1}$ rekvavapaata@yahoo.com, ${ }^{2}$ mdivanik@yahoo.com
}

Due to lack of the real strong ground motion records the objective of this research is to develop a methodology for rapid generation of horizontal and vertical components of earthquake ground motion at any site for Tbilisi city. The model developed in this study provides simulation of ground motion over a wide range of magnitudes and distances at 8 earthquake sources zones of Tbilisi region (within $50 \mathrm{~km}$ ).

The research includes three main topics: 1 ) the stochastic simulation of earthquake ground motion at a given site of the city of Tbilisi; 2) the estimation of acceleration time histories at a given site using the direct method of engineering seismology considering soil conditions based on the theory of the reflected waves and 3) calculation of horizontal and vertical acceleration elastic response spectra for main sites of Tbilisi territory.

Keywords: accelerogram, acceleration, ground motion.

\section{INTRODUCTION}

In the practice of earthquake engineering an earthquake effect quantitatively is classified according to the seismic scale and by the building code. For this purpose in the seismic scale are used Peak Ground Acceleration (PGA), Peak Ground Velocity (PGV) and Peak Ground Displacement (PGD).

In the building code the seismic action usually is represented by an elastic ground acceleration response spectra and the ground acceleration time-histories.

It should be noted that, each earthquake represents individual process, which is generated under certain geographic and geological conditions, its destructive effect first of all depends on the seismic source magnitude and the epicentral distance. The normalized elastic response spectrum shape or outlines of the spectral curves of dynamic coefficient depends on the earthquake generation mechanism and ground response in the site of interest. Therefore, the elastic response spectra defined according to the recorded accelerograms in different regions, differ from each other and reflect only local site conditions.

The time-histories dynamic analysis provides the evaluation of seismic demand of structures using the recorded and artificial or simulated accelerograms that give information on earthquake intensity, its frequency content and duration, i.e. it does not exclude time factor as it occurs in the response spectrum analysis.

Proceeding from the regulations on seismic action basic conception given in the [Eurocode 8, 1998-1:2004], selection of the elastic response spectrum shape in the country or part of the country is possible from the certain country National annexes that are worked out by local Authorities. In accordance with the recommendations suggested by Eurocode 8 deep geological data of the construction site should be considered and the horizontal and vertical elastic response spectra should be computed taking into account the seismic sources and the earthquake magnitudes generated from them. 
In general, lack of the strong earthquake records statistic package creates certain problems for the elastic response spectra and the normalized dynamic coefficient spectral curves elaboration. Note that, an example of such problems is the capital of Georgia Tbilisi city.

For Tbilisi city records of the strong earthquakes data are limited. During last 100 years at the territory of Tbilisi city about hundred weak earthquakes took place. Local strong earthquake occurred only on April 25, 2002, under the central part on the city with magnitude $\mathrm{M}=4.5$ and recorded on the bedrock peak horizontal acceleration of $0,11 \mathrm{~g}$, which was amplified to the range of 0.20 to $0.30 \mathrm{~g}$ due to dynamic response of surface soil deposits.

It is evident that, on the basis of the weak and rare earthquakes real records formation of the seismic action specified regional model is impossible. In such conditions the most straightforward procedure is to generate ground motion time histories using of regional earthquake sources zones parameters and classification according to the soils seismological and geological properties spread at Tbilisi city territory.

At the same time, according to the Georgian building code ( [Building Code, 2009] Tbilisi city is located in the seismic zone of intensity 8 degree by the MSK-64 scale, with a maximum horizontal acceleration equals $0.17 \mathrm{~g}$ and a return period of earthquakes 2500 years $(2 \%$ /in 50 years). The normalized spectral dynamic coefficient is determined for grounds of hard (I), medium (II) and soft (III) categories and without special investigations its maximum value for all three categories grounds is accepted equal to 2.5.

It should be noted, that from the earthquake source zones of Tbilisi region (within 50 $\mathrm{km})$ at the territory of the city are expected the earthquakes with magnitudes $M=5.0 \_7.0$ and corresponding seismic generated kinematics of shifting as reverse and dextral strike slip. It follows from this that it is necessary to define more precisely given in the National code the normalized spectral curves of dynamic coefficient considering the data of Tbilisi region seismological and geological properties of the grounds spread at city territory. In such conditions it is important simulation of the expected regional spatial seismic action in the form of the acceleration time-histories and elaboration the acceleration elastic response spectra and the three components spectral curves of normalized dynamic coefficient for various sites of Tbilisi city.

The objective of this study is to develop a methodology for simulation ground motions and evaluation the three components of acceleration elastic response spectra and the three components normalized spectral curves of dynamic coefficient at any site for Tbilisi city territory considering the regional seismological characteristics and geological conditions for the site of interest.

The proposed approach includes three main topics: (i) the stochastic simulation of earthquake ground motion at a given site of the city of Tbilisi; (ii) estimation of acceleration time histories at a given site using the direct method of engineering seismology taking into account a soil properties based on the theory of the reflected waves (iii) calculation of the horizontal and vertical acceleration elastic response spectra and corresponding the normalized spectral curves of dynamic coefficient for main sites of Tbilisi city territory.

\section{STOCHASTIC SIMULATION OF EARTHQUAKE GROUND MOTION}

For simulation of possible seismic ground motions on the territory of Tbilisi city in this paper is employed the discrete nonstationary Gaussian stochastic process represented as [Rekvava and Mdivani, 2010] 


$$
A_{g i}(t)=E_{i}(t) X_{i}(t)
$$

$$
(i=1,2,3)
$$

where $A_{g i}(t)$ determines of ground acceleration in the direction of three principal orthogonal axses with zero cross correlation between of components; $E_{i}(t)$ is the deterministic normalized envelope function or modulating function; $X_{i}(t)$ represents a typical realization of the stationary filtered white-noise process.

Normalized stationary random function with zero mean and unit-variance is characterized by $\mathrm{K}(\tau)$ function of correlation as

$$
K(\tau)=e^{-\alpha_{j}}|\tau|\left(\cos \omega_{j} \tau+\alpha_{j} / \omega_{j} \sin \omega_{j}|\tau|\right),
$$

where $\mathrm{K}(\tau)$ is correlation coefficient characterizing bandwidth of the process; $w$ is circular process frequency; $\mathrm{j}$ represents a ordinal number of process.

The modulating function $E_{i}(t)$ is defined in terms of so-called Berlag impulse and with $\left|\mathrm{E}_{\mathrm{i}}(\mathrm{t})\right|_{\max }=1$ is given by

$$
\mathrm{E}_{\mathrm{i}}(\mathrm{t})=\varepsilon \mathrm{t} \exp (1-\varepsilon \mathrm{t}),
$$

where e controls the shape of the envelope function and determines the effective duration and process nonstationarity.

Generalizing the form in (1), the horizontal and vertical components of the process can be written as

$$
\begin{aligned}
\mathrm{A}_{g 1}(t) & =\kappa \sigma_{1} \varepsilon t \exp (1-\varepsilon t) x_{1}(t) \\
\mathrm{A}_{g 2}(t) & =\eta \sigma_{2} \varepsilon t \exp (1-\varepsilon t) x_{2}(t) \\
\mathrm{A}_{g 3}(t) & =v \sigma_{3} \varepsilon t \exp (1-\varepsilon t) x_{3}(t),
\end{aligned}
$$

where $s_{i}$ is a mean square value of acceleration in the direction of principal axses and denotes random process intensity that is defined by its variance; $k, \eta$ da $v$ are corrective factors of the value of the horizontal and vertical components which are accordingly equal to $1,0,0,85$ and 0,7 .

Thus, the formulation in Eq.4 is completely determined with fixed values of dominant frequency $\mathrm{w}_{\mathrm{j}}$ using three parameters: $\mathrm{a}$, e and $\mathrm{s}$ which are depended on regional seismological and geological conditions or in the simple form on the earthquake magnitude, hypocentral distance, dominant frequency and ground characteristics at the site.

On the basis of propsed stochastic ground motion model formulated in Eq.4 the software package ACCSIM [Rekvava and Mdivani, 2011, Rekvava, 2009], was developed, which allows to generate the multiple artificial accelerograms of the predicted earthquakes.

\section{PARAMETERS ESTIMATIOM}

For estimation of macroseismic intensity for territory of Tbilisi city from the earthquake sources zones of Tbilisi region the two various expressions are applied [Javakhishvili et al., 1998]:

for small earthquakes $\left(\mathrm{M}_{\mathrm{s}}<6\right)$

$$
I_{T b}=1,5 M_{s}-3,4 \lg R+3,1
$$

for strong earthquakes $\left(\mathrm{M}_{\mathrm{s}}>=6\right)$

$$
I_{T b}=1,5 M_{s}-4,7 \lg R+4,0 \text {, }
$$


where $M_{s}$ is surface-wave magnitude; $R=\left(\Delta^{2}+h^{2}\right)^{1 / 2}$ is hypocentral distance; $\Delta$ is epicentral distance; $h$ is focal depth.

The resulting equation for larger horizontal values of peak horizontal acceleration is defined by [Smit et al., 2000]

$$
\log P G A_{h 1}=0,72+0,44 M_{s}-\log R-0,00231 K+0,28 p
$$

and

$$
\mathrm{K}=\sqrt{\Delta^{2}+h^{2}+4.5^{2}},
$$

where $\mathrm{p}$ is 0 for 50 -percentile values and 1 for 84 -percentile.

Empirical relations between the surface-wave magnitude of the earthquake and a hypocentral distance derived for shallow-focus near-source earthquakes under an average soil site conditions are given by the following formula [Mikhailova and Aptikaev, 1996]

$$
\lg T=0,15 M_{s}+0,25 \lg R+C_{1}+C_{2} \pm 0,2,
$$

where $C_{1}$ is parameter of fault mechanism $\left(C_{1}=-0.1\right.$ for reverse, $C_{1}=0$ for strike slip, $\mathrm{C}_{1}=0.1$ for dextral strike slip); $\mathrm{C}_{2}$ - coefficient of influence not taken into consideration factors that is equal to 1.11 ;

Duration of the ground motion is computed by

$$
\lg D=0,15 M_{s}+0,50 \lg R+C_{1}+C_{2}+C_{3} \pm 0,30,
$$

where $\mathrm{C}_{1}$ - is parameter of fault mechanism $\left(\mathrm{C}_{1}=-0.25\right.$ for reverse, $\mathrm{C}_{1}=0.0$ for strike slip, $\mathrm{C}_{1}=0.12$ for dextral strike slip; $\mathrm{C}_{2}=0.15$ for hard ground; $\mathrm{C}_{2}=0$ for medium ground; $\mathrm{C}_{2}=0.15$ for soft ground; a mean value of ratio $\mathrm{C}_{3}$ is equal to 1.3 .

The calculated parameters for the borderline territory of Tbilisi city are listed in Table 1. It should be noted that for computation of PGA has been used 84-percentile. On the basis of empirical data the more intensive horizontal component of $\mathrm{PGA}_{\mathrm{h} 1}$ is obtained 1.28 times greater than other one and the vertical component is $2 / 3$ of the maximum horizontal component.

\begin{tabular}{|c|c|c|c|c|c|c|c|}
\hline Zone $^{1}$ & $\begin{array}{c}\mathrm{R} \\
(\mathrm{km})\end{array}$ & $\begin{array}{c}\mathrm{I}_{\mathrm{TB}} \\
(\mathrm{deg})\end{array}$ & $\begin{array}{c}\mathrm{T} \\
(\mathrm{sec})\end{array}$ & $\begin{array}{c}\mathrm{D} \\
(\mathrm{sec})\end{array}$ & $\begin{array}{c}\mathrm{PGA}_{\mathrm{hl}} \\
\left(\mathrm{m} / \mathrm{sec}^{2}\right)\end{array}$ & $\begin{array}{c}\mathrm{PGA}_{\mathrm{h} 2} \\
\left(\mathrm{~m} / \mathrm{sec}^{2}\right)\end{array}$ & $\begin{array}{l}\mathrm{PGA}_{\mathrm{h} 3} \\
\left(\mathrm{~m} / \mathrm{sec}^{2}\right)\end{array}$ \\
\hline \multicolumn{8}{|c|}{ From focus with $M=5$} \\
\hline 2 & 10.6 & 7 & 0.13 & 1.63 & 2.11 & 1.65 & 1.41 \\
\hline 5 & 8.38 & 7 & 0.12 & 1.45 & 2.20 & 1.72 & 1.47 \\
\hline \multicolumn{8}{|c|}{ From focus with $\mathrm{M}=5.5$} \\
\hline 7 & 10.7 & 8 & 0.15 & 2.06 & 2.38 & 1.86 & 1.59 \\
\hline \multicolumn{8}{|c|}{ From focus with $M=6$} \\
\hline 4 & 11.2 & 8 & 0.18 & 2.66 & 2.53 & 1.98 & 1.69 \\
\hline 6 & 10.0 & 8 & 0.18 & 2.51 & 2.57 & 2.01 & 1.72 \\
\hline 8 & 16.0 & 7 & 0.2 & 3.18 & 2.38 & 1.86 & 1.67 \\
\hline \multicolumn{8}{|c|}{ From focus with $\mathrm{M}=6.5$} \\
\hline 1 & 29.4 & 7 & 0.28 & 5.42 & 2.32 & 1.81 & 1.55 \\
\hline \multicolumn{8}{|c|}{ From focus with $\mathrm{M}=7$} \\
\hline 3 & 16.3 & 9 & 0.28 & 5.08 & 2.81 & 2.20 & 1.88 \\
\hline
\end{tabular}

Table 1 .

Quantitative Characteristics of the Predicted Ground Motion on the Borderline of Tbilisi City 
For 10 sites of Tbilisi city territory (350 square kilometers) were also determined (Fig. 1) minimum hypocentral distances, PGA for $2 \%$ and $1 \%$ probabilities of being exceeded in 50 years, values of the dominant periods and duration of oscillation. As an illustration in Table 2 are given parameters generated from the high potential seismic generating zone \#3 which is situated to the north-west of Tbilisi region. Note, that values of PGA in Table 2 correspond to $2 \%$ probability of being exceeded in 50 years and are by $15 \%$ less than computed for $1 \%$ probability of being exceeded in 50 years.

The main parameter $\omega_{j}$ of the ground motion model has been determined based on the Eq.9 using the expression:

$$
\omega_{j}=2 \pi / T_{j}(11)
$$

The value of the correlation degree characterizing parameter a was evaluated based on the analysis of the Georgian earthquakes records data, [Rekvava and Mdivani, 2011] depending on $\mathrm{w}$ and for $1(\mathrm{x}), 2$ (y) and $3(\mathrm{z})$ components consists of

$$
\alpha_{j 1}=0.204 w_{j} ; \alpha_{j 2}=0.253 w_{j} ; \alpha_{j 3}=0.41 w_{j} ;
$$

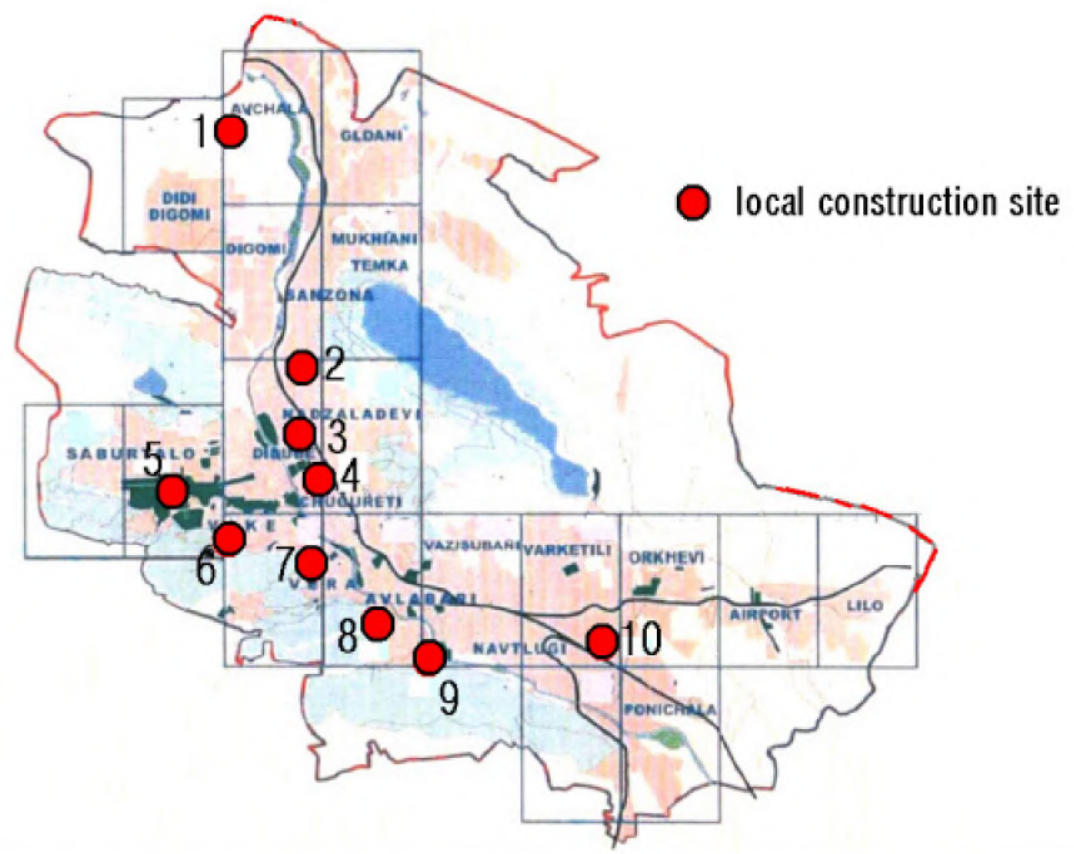

Figure 1. Location of the sites on the territory of the city

The mean square value of acceleration s was accepted considering that

$$
\sigma_{i}=P G A_{i} / 3, i=1,2,3
$$

The parameter $\mathrm{e}$ is determined on the basis of the given duration of intensive iscillations above-mentioned records and is equal to

$$
\varepsilon_{j}=0.02 \omega_{j}
$$

Thus calculated parameters are represented in Table 3, but mean square values of the horizontal and vertical accelerations for earthquake generated from the high potential seismic generating zone № 3 are given in Table 4 . 
Table 2 .

Quantitative Characteristics of the Predicted Ground Motion for the Concrete Sites of Tbilisi City

\begin{tabular}{|c|c|c|c|c|c|c|c|c|c|c|c|c|}
\hline \multirow[t]{2}{*}{ Zone $^{1}$} & \multirow[t]{2}{*}{ M } & \multirow[t]{2}{*}{ Parameters } & \multicolumn{10}{|c|}{ Site $^{1}$} \\
\hline & & & 1 & 2 & 3 & 4 & 5 & 6 & 7 & 8 & 9 & 10 \\
\hline \multirow{6}{*}{3} & \multirow{6}{*}{7} & $\mathrm{R}_{\min }, \mathrm{km}$ & 15.6 & 20.0 & 21.2 & 23.3 & 18.1 & 21.6 & 25.1 & 26.8 & 30.0 & 33.7 \\
\hline & & $\begin{array}{l}\mathrm{PGA}_{\mathrm{hl}}, \\
\left(\mathrm{m} / \mathrm{sec}^{2}\right)\end{array}$ & 2.83 & 2.72 & 2.69 & 2.65 & 2.77 & 2.69 & 2.62 & 2.58 & 2.53 & 2.47 \\
\hline & & $\begin{array}{l}\mathrm{PGA}_{\mathrm{h} 2}, \\
\left(\mathrm{~m} / \mathrm{sec}^{2}\right)\end{array}$ & 2.21 & 2.13 & 2.10 & 2.07 & 2.16 & 2.10 & 2.04 & 2.02 & 1.98 & 1.93 \\
\hline & & $\begin{array}{l}\mathrm{PGA}_{\mathrm{h} 3}, \\
\left(\mathrm{~m} / \mathrm{sec}^{2}\right)\end{array}$ & 1.89 & 1.81 & 1.80 & 1.77 & 1.85 & 1.79 & 1.74 & 1.72 & 1.69 & 1.65 \\
\hline & & $\mathrm{T}, \mathrm{sec}$ & 0.281 & 0.299 & 0.303 & 0.31 & 0.291 & 0.305 & 0.316 & 0.321 & 0.331 & 0.34 \\
\hline & & $\mathrm{D}, \mathrm{sec}$ & 4.98 & 5.63 & 5.8 & 6.08 & 5.35 & 5.86 & 6.3 & 6.52 & 6.9 & 7.31 \\
\hline
\end{tabular}

Table 3 .

Parameters for Genaration of Regional Synthetic Accelerograms

\begin{tabular}{|c|c|c|c|c|c|c|}
\hline Zone $^{1}$ & $\begin{array}{c}\omega_{\mathrm{j}} \\
\sec ^{-1}\end{array}$ & $\begin{array}{c}\alpha_{\mathrm{j} 1} \\
\sec ^{-1}\end{array}$ & $\begin{array}{c}\alpha_{\mathrm{j} 2} \\
\mathrm{sec}^{-1}\end{array}$ & $\begin{array}{c}\alpha_{j 3} \\
\sec ^{-1}\end{array}$ & $\begin{array}{c}\varepsilon_{\mathrm{j}} \\
\sec ^{-1}\end{array}$ & $\begin{array}{c}\Delta \mathrm{t}=0.04 \mathrm{~T}_{\mathrm{j}} \\
\quad \sec \end{array}$ \\
\hline \multicolumn{7}{|c|}{ From focus with $M=5$} \\
\hline 2 & 48.3 & 9.85 & 12.1 & 19.8 & 0.97 & 0.005 \\
\hline 5 & 52.3 & 10.67 & 13.1 & 21.4 & 1.05 & 0.0048 \\
\hline \multicolumn{7}{|c|}{ From focus with $\mathrm{M}=5.5$} \\
\hline 7 & 41.8 & 8.53 & 10.5 & 17.1 & 0.84 & 0.006 \\
\hline \multicolumn{7}{|c|}{ From focus with $M=6$} \\
\hline 4 & 34.8 & 7.1 & 8.7 & 14.3 & 0.7 & 0.007 \\
\hline 6 & 34.8 & 7.1 & 8.7 & 14.3 & 0.7 & 0.007 \\
\hline 8 & 31.4 & 6.4 & 7.9 & 12.9 & 0.63 & 0.008 \\
\hline \multicolumn{7}{|c|}{ From focus with $\mathrm{M}=6.5$} \\
\hline 1 & 22.4 & 4.5 & 5.6 & 9.2 & 0.45 & 0.011 \\
\hline \multicolumn{7}{|c|}{ From focus with $\mathrm{M}=7$} \\
\hline 3 & 22.4 & 4.6 & 5.6 & 9.2 & 0.45 & 0.011 \\
\hline
\end{tabular}

Table 4

Mean Square Values of Aaccelerations for Concrete Sites from Zone $\mathbf{1 3}$

\begin{tabular}{|c|c|c|c|c|c|c|c|c|c|c|c|}
\hline \multirow{2}{*}{$\begin{array}{l}\text { Mean square } \\
\text { value of accel- } \\
\text { eration } \mathrm{m} / \mathrm{sec}^{2}\end{array}$} & \multirow{2}{*}{$\begin{array}{l}\text { Probabiliy } \\
\text { of exceeding } \\
\text { in } 50 \text { years }\end{array}$} & \multicolumn{10}{|c|}{ Site $^{1}$} \\
\hline & & 1 & 2 & 3 & 4 & 5 & 6 & 7 & 8 & 9 & 10 \\
\hline \multirow{2}{*}{$\sigma_{1}$} & $2 \% / 50$ & 94 & 91 & 90 & 88 & 92 & 90 & 87 & 84 & 84 & 82 \\
\hline & $1 \% / 50$ & 109 & 104 & 103 & 102 & 106 & 103 & 100 & 97 & 97 & 95 \\
\hline \multirow[b]{2}{*}{$\sigma_{2}$} & $2 \% / 50$ & 73 & 71 & 70 & 69 & 72 & 70 & 68 & 67 & 66 & 64 \\
\hline & $1 \% / 50$ & 85 & 81 & 81 & 79 & 83 & 80 & 78 & 77 & 76 & 74 \\
\hline \multirow[b]{2}{*}{$\sigma_{3}$} & $2 \% / 50$ & 63 & 60 & 60 & 59 & 62 & 60 & 58 & 57 & 56 & 55 \\
\hline & $1 \% / 50$ & 72 & 70 & 69 & 68 & 71 & 69 & 67 & 66 & 65 & 63 \\
\hline
\end{tabular}




\section{DETERMINATION OF MULTILAYER GROUND MOTION BASED ON THE THEORY OF REFLECTED WAVES}

Method of the multiple reflected waves gives a possibility to determine for a certain concrete territory by geologic profile conformity to natural laws of seismic oscillation of the multilayer ground surface, under motion of bedrock as foundation according a law of given accelerogram.

For analytical drawing of accelerogram of the ground surface oscillation let consider, a wave picture at any time in the ground area, with different thickness and horizontal borderline. It is accepted an assumption that the ground is elastic and waves are propagated in the vertical direction (Fig. 2). In the form of seismic influence in this case is used recorded on the bedrock accelerogram from the database of ground motions with known earthquake [Rekvava and Mdivani, 2011].

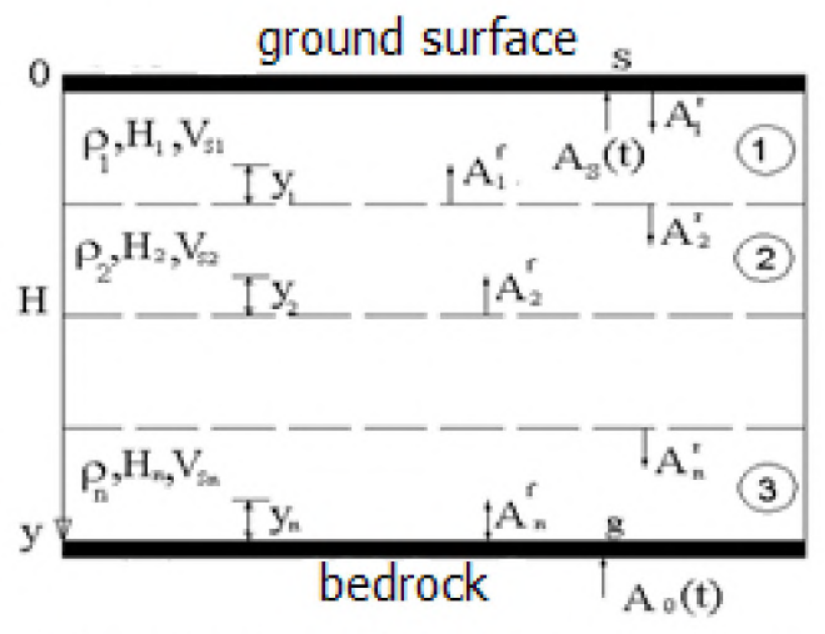

Figure 2. Design model of non-homogeneous ground

In the Fig. 2 are accepted following designations: $A_{i}^{f}(t)$ is value of the wave function at the $t$ time on the bottom level of the $\mathrm{i}$-th layer; $A_{i}^{r}(t)$ is value of the wave function at the $t$ time on the top level of the i-th layer; $A_{0}(t)$ is the given relationship of the movement on the level of bedrock.

For any i-th layer of ground the wave equation of shear oscillations can be written as [Napetvaridze, 1973]:

$$
\frac{\partial^{2} A_{i}(t)}{\partial t^{2}}-V_{s i}^{2} \frac{\partial^{2} A_{i}(t)}{\partial y^{2}}=0,
$$

where $A_{i}(\mathrm{t})$ is the displacement of ground $\mathrm{i}$-th layer particles; $\mathrm{t}$ is the time; y represents the coordinate of particle oscillation in the $\mathrm{v}$ ertical direction; $\mathrm{V}_{\mathrm{s}}$ is the velocity of the shear wave propagation in the ground area.

Solution of the Eq. 15 on the top of the $\mathrm{i}$-th layer at the $\mathrm{t}$ time is given by

$$
A_{i}^{r}(t)=\alpha_{i-1, i} A_{i-1}^{r}\left(t-\tau_{i-1}\right)+\beta_{i, i-1} A_{i}^{f}\left(t-\tau_{i}\right),
$$

where $\alpha_{i, i-1}$ is the factor of refraction under passing of wave from i-1-th to i-th layer; $\beta_{i, i-1}$ the factor of wave reflection on the borderline between i and i-1 layers; $\tau_{i}$ represents the time of wave passage in the i-th layer $\left(\tau_{i}=H_{i} / V_{s i}\right.$, where $H_{i}$ and $V_{s i}$ are accordingly the thickness of ground layer and the velocity of the shear wave propagation in the i-th layer).

$\alpha$ and $\beta$ factors are defined by

$$
\begin{gathered}
\alpha_{i-1, i}=2 \rho_{i-1} V_{s, i-1} /\left(\rho_{i-1} V_{s, i-1}+\rho_{i} V_{s i}\right) \\
\beta_{i, i-1}=\left(V_{s i} \rho_{i}-\rho_{i-1} V_{s, i-1}\right) /\left(V_{s i} \rho_{i}+V_{s, i-1} \rho_{i-1}\right),
\end{gathered}
$$

where $\rho_{i}$ is a density of $\mathrm{i}$-th ground layer. 
Hence, finally solution of the direct problem of engineering seismology can be represented by the recurrent relations as [Napetvaridze, 1973]:

$$
\begin{aligned}
& A_{1}^{r}(t)=A_{1}^{f}\left(t-\tau_{1}\right), \\
& A_{1}^{f}(t)=\alpha_{2,1} A_{2}^{f}\left(t-\tau_{2}\right)+\beta_{1,2} A_{1}^{r}\left(t-\tau_{1}\right), \\
& A_{2}^{r}(t)=\alpha_{2,1} A_{1}^{r}\left(t-\tau_{1}\right)+\beta_{2,1} A_{2}^{f}\left(t-\tau_{2}\right), \\
& A_{2}^{f}(t)=\alpha_{3,2} A_{3}^{f}\left(t-\tau_{3}\right)+\beta_{2,3} A_{2}^{r}\left(t-\tau_{2}\right), \\
& A_{i}^{r}(t)=\alpha_{i-1, i} A_{i-1}^{r}\left(t-\tau_{i-1}\right)+\beta_{i, i-1} A_{i}^{f}\left(t-\tau_{i}\right), \\
& A_{i}^{f}(t)=\alpha_{i+1, i} A_{i+1}^{r}\left(t-\tau_{i+1}\right)+\beta_{i, i+1} A_{i}^{r}\left(t-\tau_{i}\right), \\
& A_{n}^{r}(t)=\alpha_{n-1, n} A_{n-1}^{r}\left(t-\tau_{n-1}\right)+\beta_{n, n-1} A_{n}^{f}\left(t-\tau_{n}\right), \\
& A_{n}^{f}(t)=\alpha_{n+1, n} A_{0}(t)+\beta_{n, n+1} A_{n}^{r}\left(t-\tau_{n}\right) .
\end{aligned}
$$

Value of the wave function from the bottom of i-th layer on the level of $y_{i}$ can be calculated according to

$$
A_{i}^{y_{i}}(t)=A_{i}^{f}\left(t-y_{i} / V_{s i}\right)+A_{i}^{r}\left(t-\left(H_{i}-y_{i}\right) / V_{s i}\right)
$$

Thus, the developed algorithm of solution the direct problem of engineering seismology is realized by the software package GAFART [Rekvava and Mdivani, 2011].

\section{SIMULATION RESULTS FOR TBILISI CITY SITES}

The computer code ACCSIM was used for generation of the horizontal and vertical components of synthetic accelerograms corresponding possible seismic source zones of Tbilisi region, given in Table 1. Discrete step of the simulated accelerograms was taken equal to $0,04 \mathrm{~T}$. When assessing the probabilistic mean acceleration elastic response spectra and the normalized dynamic coefficient spectral curves for all sites, which are presented in Fig. 1, the required number of realizations was reduced for each synthetic accelerogram up to 20 realizations. The most novel aspect of this extension is elaboration of proper the three-components normalized dynamic coefficient spectral curves, which are computed for a 50 years exposure time and $2 \%$ and $1 \%$ probabilities of exceeding.

In Table 5 are represented values of the probabilistic mean normalized spectral dynamic coefficient of synthetic motion, generated from the source zones N3 and N6 for the sites situated in the centre of Tbilisi city.

As an example, Fig. 3 shows pairs of the probabilistic mean elastic acceleration response spectra for 5\% damping and the corresponding spectral curve of normalized dynamic coefficient of synthetic motion, generated from the source zone N3, for site ${ }^{1} 8$ of soft soil characteristics for $2 \%$ in 50 years.

Using the software GAFART was studied an influence of a typical earthquake and local geological conditions upon forming the elastic acceleration response spectra for the abovementioned sites. With that and in view from the data set, [Rekvava and Mdivani, 2011], was selected five recorded on the bedrock accelerograms (EL Centro-1940, $M=6.7$, Santa Barbara-1980, Montenegro-1979, $M=7.0$, Friuli 1976, $M=6.0$, and Tbilisi-2002, $M=4.5$ ), which are different from each other by parameters of PGA, dominant period and duration, but by the magnitude and epicentral distance are close to predicted earthquakes characteristics for Tbilisi region.

Considering the soil profile properties (thickness, density, shear wave velocity) of 
Table 5.

Maximum Values of Normalized Dynamic Coefficient for 2\%/50 and 1\%/50 years

\begin{tabular}{|c|c|c|c|c|c|c|c|c|c|c|c|c|c|c|}
\hline \multirow[t]{4}{*}{ Zone $^{1}$} & \multirow[t]{4}{*}{$\mathrm{M}$} & \multirow[t]{4}{*}{ Axes } & \multicolumn{12}{|c|}{ Site $^{1}$} \\
\hline & & & \multicolumn{2}{|c|}{ N1 } & \multicolumn{2}{|c|}{ N2 } & \multicolumn{2}{|c|}{ N5 } & \multicolumn{2}{|c|}{ N7 } & \multicolumn{2}{|c|}{ N8 } & \multicolumn{2}{|c|}{ N10 } \\
\hline & & & \multicolumn{2}{|c|}{$\beta_{\max }$} & \multicolumn{2}{|c|}{$\beta_{\max }$} & \multicolumn{2}{|c|}{$\beta_{\max }$} & \multicolumn{2}{|c|}{$\beta_{\max }$} & \multicolumn{2}{|c|}{$\beta_{\max }$} & \multicolumn{2}{|c|}{$\beta_{\max }$} \\
\hline & & & $2 \%$ & $1 \%$ & $2 \%$ & $1 \%$ & $2 \%$ & $1 \%$ & $2 \%$ & $1 \%$ & $2 \%$ & $1 \%$ & $2 \%$ & $1 \%$ \\
\hline \multirow{3}{*}{3} & \multirow{3}{*}{7} & $\mathrm{x}$ & 2.5 & 2.7 & 2.4 & 2.5 & 2.5 & 2.8 & 2.4 & 3.0 & 2.5 & 3.0 & 2.4 & 2.6 \\
\hline & & $y$ & 1.8 & 2.2 & 2.0 & 2.4 & 2.6 & 3.0 & 2.2 & 2.6 & 2.5 & 2.5 & 2.5 & 2.7 \\
\hline & & $\mathrm{Z}$ & 2.2 & 3.0 & 2.7 & 3.0 & 1.8 & 3.0 & 2.1 & 2.2 & 2.6 & 2.8 & 1.8 & 2.3 \\
\hline \multirow{3}{*}{6} & \multirow{3}{*}{6} & $\mathrm{x}$ & 2.6 & 3.0 & 2.0 & 2.9 & 3.0 & 3.7 & 2.4 & 2.5 & 2.6 & 3.2 & 2.3 & 2.5 \\
\hline & & $\mathrm{y}$ & 2.5 & 2.7 & 2.0 & 2.5 & 2.5 & 3.0 & 2.2 & 2.5 & 2.5 & 3.0 & 2.3 & 2.5 \\
\hline & & $z$ & 3.0 & 3.4 & 2.5 & 2.7 & 2.7 & 3.0 & 3.3 & 3.5 & 2.5 & 2.8 & 2.0 & 2.5 \\
\hline
\end{tabular}
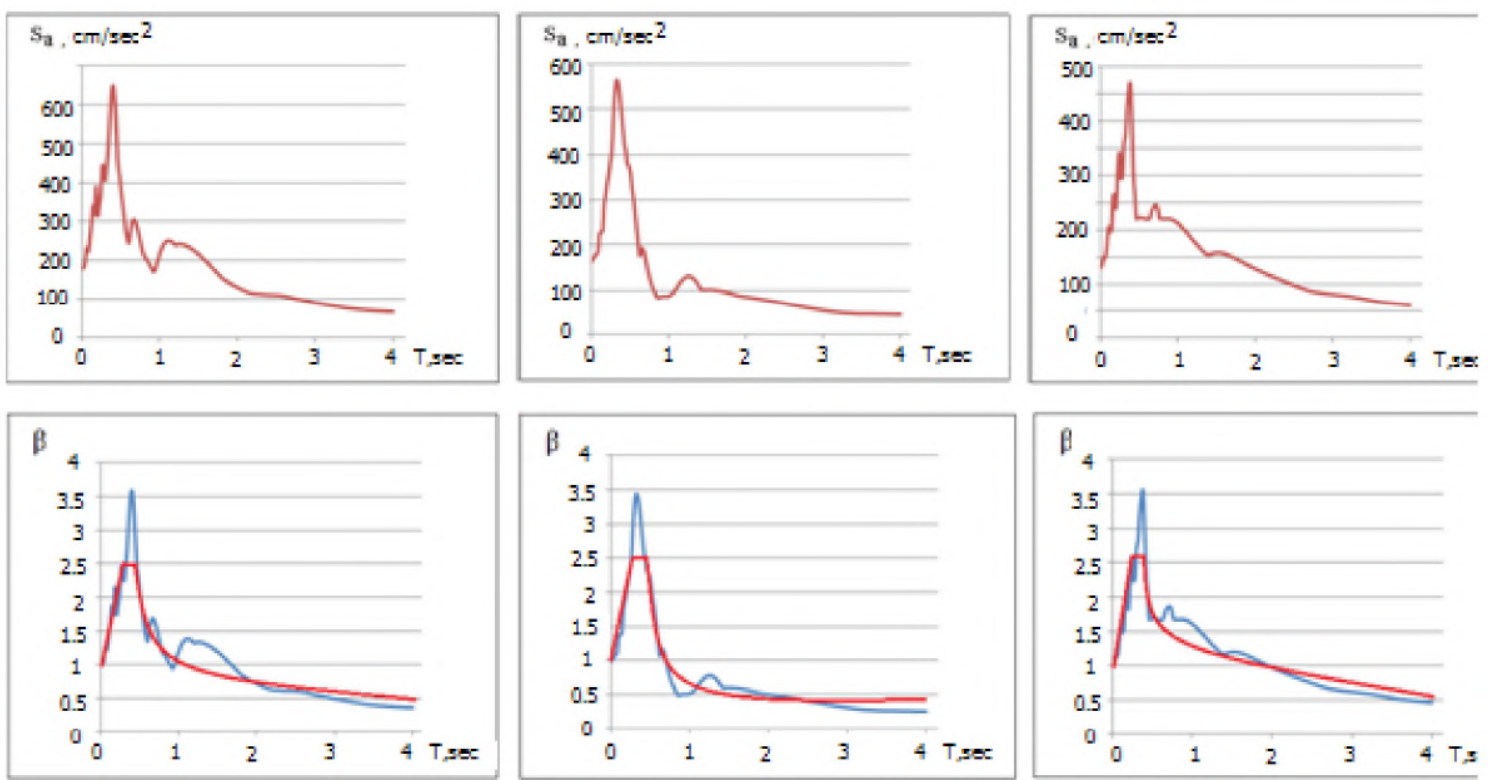

Figure 3. Generated from zone № 3 for site № 8 x,y,z components of acceleration response spectra (a) and spectral curves of normalized dynamic coefficient for $2 \%$ in 50 years.

these sites, received from geological test, on the basis of the abovementioned recorded ground motions were calculated the three components of time-histories on the ground surface of the sites. Then at the final phase of analysis the three components of spectral curves of normalized dynamic coefficient have been plotted. Table 6 displays the effect of local soil condition on the dynamic coefficient.

Fig. 4 displays the effect of local soil condition on the normalized dynamic coefficient for the concrete site $^{1} 8$ under action of Tbilisi-2002 records.

According to the obtained results was computed value of the relative seismic factor or soil amplification factor as the ratio of the maximum accelerations of the ground surface layer to the bedrock. The analysis shows that in the given soil properties of the sites under investigation the seismic factor is changed from 1,5 to 2,6 .

\section{CONCLUSIONS}

The complex approach of simulation ground motion and construction the horizontal 
Table 6.

Maximum Values of Normalized Dynamic Coefficient from Different Earthquakes

\begin{tabular}{|c|c|c|c|c|c|c|c|c|}
\hline \multirow{3}{*}{1} & \multirow{3}{*}{ Earthquake } & \multirow{3}{*}{ Component } & \multicolumn{6}{|c|}{ Site $^{1}$} \\
\hline & & & N1 & $\mathrm{N} 2$ & N5 & N7 & N8 & N10 \\
\hline & & & $\beta_{\max }$ & $\beta_{\max }$ & $\beta_{\max }$ & $\beta_{\max }$ & $\beta_{\max }$ & $\beta_{\max }$ \\
\hline \multirow{3}{*}{1} & \multirow{3}{*}{ EL Centro } & $x$ & 2.2 & 3.0 & 3.0 & 2.5 & 3.0 & 2.5 \\
\hline & & $\mathrm{y}$ & 2.2 & 3.0 & 3.0 & 2.5 & 3.0 & 2.5 \\
\hline & & $\mathrm{z}$ & 2.2 & 3.0 & 3.0 & 2.5 & 3.0 & 2.5 \\
\hline \multirow{3}{*}{2} & \multirow{3}{*}{ Santa Barbara } & $\mathrm{x}$ & 2.7 & 3.5 & 4.0 & 3.0 & 2.5 & 2.7 \\
\hline & & $\mathrm{y}$ & 2.7 & 3.5 & 4.0 & 3.0 & 2.5 & 2.5 \\
\hline & & $\mathrm{z}$ & 2.7 & 3.5 & 4.0 & 3.0 & 2.5 & 2.4 \\
\hline \multirow{3}{*}{3} & \multirow{3}{*}{ Montenegro } & $\mathrm{x}$ & 2.5 & 3.5 & 2.5 & 3.0 & 4.0 & 2.5 \\
\hline & & $\mathrm{y}$ & 2.0 & 3.0 & 3.0 & 3.7 & 3.0 & 2.5 \\
\hline & & $\mathrm{z}$ & 3.0 & 2.5 & 2.7 & 3.0 & 2.0 & 3.0 \\
\hline \multirow{3}{*}{4} & \multirow{3}{*}{ Friuli } & $\mathrm{x}$ & 2.4 & 3.0 & 3.5 & 3.0 & 3.0 & 2.8 \\
\hline & & $y$ & 2.7 & 3.3 & 3.0 & 2.8 & 2.5 & 2.7 \\
\hline & & $\mathrm{z}$ & 1.8 & 3.0 & 2.3 & 2.3 & 2.5 & 2.5 \\
\hline \multirow{3}{*}{5} & \multirow{3}{*}{ Tbilisi } & $x$ & 2.5 & 2.0 & 2.1 & 2.5 & 2.3 & 2.3 \\
\hline & & $\mathrm{y}$ & 2.5 & 2.2 & 3.1 & 2.0 & 2.5 & 2.5 \\
\hline & & $\mathrm{z}$ & 2.3 & 2.3 & 2.4 & 3.0 & 2.1 & 2.2 \\
\hline
\end{tabular}

a)
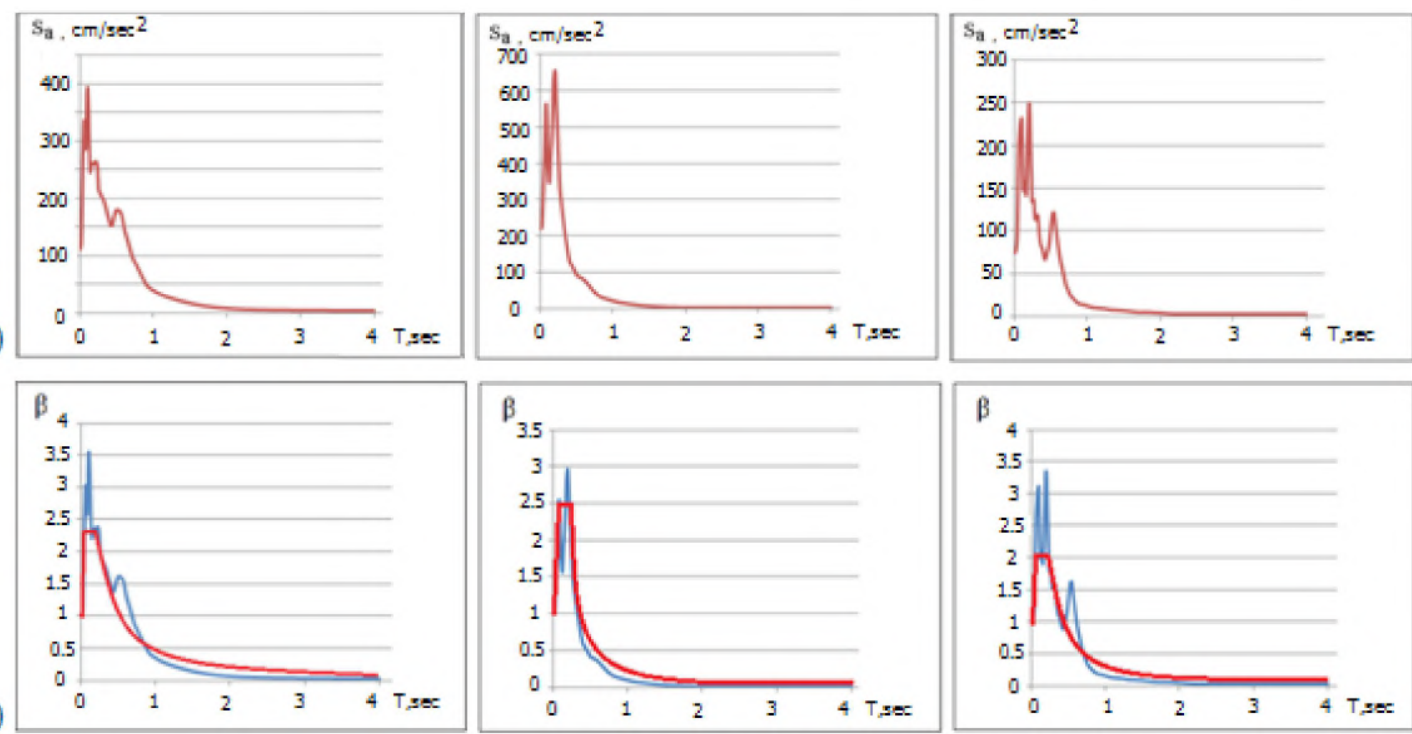

Figure 4. Three components acceleration response spectra (a) and spectral curves of normalized dynamic coefficient (b) for site № 8 resulting from the accelerogram calculated at the free surface from recording

"Tbilisi-2002» of the depth $z=-43,1 \mathrm{~m}$

and vertical acceleration elastic response spectra and corresponding normalized dynamic coefficient spectral curves are proposed, which account for the location of the earthquake source zones and seismological and geological characteristics of the Tbilisi region territory and concrete construction sites of the Tbilisi city.

Based on the empirical relations and characteristics of the earthquake source zones the values of mean accelerations of ground motion for $2 \% /$ and $1 \%$ probabilities of being exceeded in 50 years expected in the sites of Tbilisi city has been determined and appropriate probabilistic horizontal and vertical acceleration elastic response spectra and normalized spectral dynamic coefficients are calculated which can be used in seismic design 
and analysis of structures.

On the territory under examination for the concrete construction sites in result of experimental research the dynamic parameters of soil geological layers are determined and based on the theory of reflected waves the ground motion for the sites of Tbilisi city horizontal and vertical acceleration elastic response spectra and normalized spectral dynamic coefficients are calculated and their corrected shapes considering the local sites conditions for medium (II) and soft (III) categories of soil are constructed.

The value of the relative seismic factor as the ratio of the maximum accelerations of the ground surface layer to the bedrock, in the given soil properties of the sites under investigation, is changed from 1,5 to 2,6 .

\section{REFERENCES}

1. Eurocode 8: Design of structures for earthquake resistance, part 2: General rules, seismic actions and rules for buildings (European Standard EN 1998-1:2004)

2. Building Code (2009) «Earthquake Engineering PN 01.01-09», Georgian Ministry of Economic Development, Tbilisi, Georgia

3. Javakhishvili Z., Varazanashvili O., Butikashvili N. (1998) «Interpretation Macroseismic Valley of Georgia», Journal of Georgian Geophysical Society 3:85-8

4. Mikhailova N. and Aptikaev F. (1996) «Some Correlation Relations between Parameters of Seismic Motion», Journal Of Earthquake Prediction Reserch 5: 2, 257-263

5. Napetvaridze Sh. (1973) Some Problems of Engineering Seismology,Mecniereba, Tbilisi, Georgia

6. Rekvava P. (2009) Modern Earthquake Engineering, Intellect, Tbilisi, Georgia.

7. Rekvava P. and Mdivani K. (2010) «Modeling of Earthquake Ground Motion for Tbilisi Region», Global Journal of Researches in Engineering. Revolutions in Engineering 10: 3, 2-7

8. Rekvava P. and Mdivani, K. (2011) «Elaboration of the Seismic Influence Spatial Models for Performance-Based Design Considering Seismological and Engineering-Geological Conditions of Tbilisi Region» Georgian National Science Foundation, Grant N GNSF/ST08/7-484

9. Smit P., Arzumznian V., Javakhishvili Z., Arefiev S., Mayer-Rosa D., Balassanian S. and Chelidze T. (2000) «The Digital Accelerograph Network in the Caucasus», Earthquake Hazard and Seismic Risk Reduction, 109-118 
DOI: $10.23671 /$ NNC.2014.2.55435

\section{НОРМИРОВАННОЕ УСКОРЕНИЕ СПЕКТРА РЕАКЦИИ ДЛЯ ГОРОДА ТБИЛИСИ С УЧЕТОМ СЕЙСМОЛОГИЧЕСКИХ ПАРАМЕТРОВ И ВЛИЯНИЯ ГРУНТОВЫХ УСЛОВИЙ}

\section{() 2014 П.А. Реквава', доктор наук, профессор, К. Мдивани², доктор наук}

Грузинская национальная ассоциация сейсмостойкого строительства и инженерной сейсмологии, Тбилиси, Грузия, ${ }^{1}$ rekvavapaata@yahoo.com;

2mdivanik@yahoo.com

Из-за отсутствия реальных записей сильных движений целью данного исследования является разработка методологии для быстрой генерации горизонтальных и вертикальных составляющих грунтовых движений землетрясения на любом участке для города Тбилиси. Модель, разработанная в результате исследования, обеспечивает имитацию движений грунта в широком диапазоне магнитуд и расстояний при 8 очагах землетрясений в регионе Тбилиси (в пределах 50 км).

Исследование включает в себя три основные темы: 1) стохастическое моделирования грунтовых движений при землетрясении для данного участка города Тбилиси; 2) оценка записей ускорения в данном участке, используя прямой метод инженерной сейсмологии, рассматривая грунтовые условия, основываясь на теории отраженных волн 3) расчет горизонтального и вертикального спектров упругой реакции ускорения для основных участков территории Тбилиси.

Ключевые слова: акселерограмма, ускорение, грунтовые движения. 